\title{
Influencia de la conductividad y fuerza iónica de soluciones sintéticas que simulan la fase acuosa del hormigón en el fenómeno de la corrosión de armaduras $\left.{ }^{\star}\right)(1)$
}

\author{
Influence of the conductivity and the ionic strength \\ of synthetic solutions which simulate the aquouse \\ phase of concrete in the corrosion process
}

\begin{abstract}
RESUMEN
Este trabajo presenta el estudio cuantitativo, mediante la técnica de Resistencia de Polarización (Rp), de la influencia de los iones $\mathrm{Cl}^{-}$y $\mathrm{OH}^{-}$en la corrosión de armaduras de acero, en un medio acuoso sintético de similar composición al contenido en los poros del hormigón. Fuerza iónica, conductividad (resistividad) y sus variaciones en función de la concentración de dichos iones, han sido los parámetros de interés escogidos para la evaluación del proceso, además de las medidas de intensidad y potenciales de corrosión. Los resultados muestran claramente el antagonismo de los iones $\mathrm{Cl}^{-}$y $\mathrm{OH}^{-}$, cuyo carácter agresivo o protector disminuye a medida que aumenta la fuerza iónica del medio.

S. GOÑI, A. MORAGUES y C. ANDRADE Dres. en Quimica ICCET/CSIC ESPAÑA

\begin{abstract}
Polarization Resistance $(R p)$ has been the electrochemical technique employed to study quantitatively the influence of $\mathrm{Cl}^{-}$and $\mathrm{OH}^{-}$ions on the corrosion of steel reinforcing, in a synthetic aqueous medium of similar composition to those of the concrete pore solution. Ionic strenght, resistibity and their variations in function of $\mathrm{Cl}^{-}$and $\mathrm{OH}^{-}$ concentration have been chosen as more interesting solution parameters, together with intensity and potential corrosion measurements. The results showed the clear antagonistic role played by $\mathrm{Cl}^{-}$and $\mathrm{OH}^{-}$ions on the corrosion process, which decreased as ionic strenght increased.
\end{abstract}

\section{INTRODUCCION}

El hormigón es un material pétreo y poroso que contiene en sus poros una solución alcalina de elevado $\mathrm{pH}$ (entre 12 y 14). Esta alcalinidad mantiene pasivo al acero de las armaduras durante periodos de tiempo indefinidos.

Las dos circustancias principales, que pueden provocar la corrosión del acero dentro del hormigón, son la presencia de iones $\mathrm{Cl}^{-} \mathrm{ola}$ carbonatación del material por reacción con el

\section{INTRODUCTION}

Concrete is a stonelike and porous material containing in its voids an alkaline solution with high $\mathrm{pH}$ (range 12-14). This alkalinity keeps the steel passivate in the reinforcements for indefinite period of time.

The two major reasons which may produce the corrosion of steel within the concrete are the presence of $\mathrm{Cl}^{-}$ions or the material carbonation by reaction with atmospheric $\mathrm{CO}_{2}$.

(*) Reproducción permitida mediante autorización del autor.

(1) Contribución técnica presentada en el $11^{\circ}$ SEMINARIO NACIONAL DE CORROSION DE ABRACO. 
$\mathrm{CO}_{2}$ atmosférico. Tanto con la carbonatación como cuando los cloruros penetran desde el exterior, en la vida útil de una estructura que se corroe, se distinguen dos períodos (1): a) un período de iniciación que comprende el tiempo que tarda el agresivo en llegar hasta la armadura, momento en el que el acero se despasiva, y b) un período de propagación en el que el acero se corroe activamente.

En el caso de los cloruros, hasta el presente, se han realizado muchos trabajos (2-4) relacionados con el potencial de ruptura (Er), o con la cantidad de cloruros necesaria para despasivar las armaduras en un medio tan alcalino (límite de $\mathrm{Cl}^{-} / \mathrm{OH}^{-}$). Sin embargo, son mucho menos numerosos los trabajos que tratan de relacionar la cantidad de cloruros y la velocidad de corrosión de las armaduras, esto es, su influencia en el período de propagación de la corrosión.

La velocidad de corrosión del acero, en hormigón, depende fundamentalmente del contenido en humedad (que a su vez fija la disponibilidad de $\mathrm{O}_{2}$ y la resistividad) y de la temperatura. Cuando la corrosión es debida a los cloruros, existen evidencias experimentales (5-7) de que éstos ejercen también una influencia en la velocidad de corrosión, pero sin que se hayan establecido unas relaciones cuantitativas entre ambos.

Los autores, tratando de explorar sistemáticamente los parámetros que influencian la velocidad de corrosión del acero en hormigón, presentan en este trabajo resultados de corrosión del acero en disoluciones que simulan la fase acuosa del hormigón, conteniendo cloruros. Para ello, han preparado soluciones de $\mathrm{pH}$ comprendido entre 11,64 y 13,22, con diversas adiciones de $\mathrm{NaCl}$ y $\mathrm{CaCl}_{2}$. Estas disoluciones han sido caracterizadas mediante su fuerza iónica, resistividad y relación $\left[\mathrm{Cl}^{-}\right] /\left[\mathrm{OH}^{-}\right]$, y se han relacionado estos parámetros con la velocidad de corrosión obtenida de medidas de Resistencia de Polarización.

\section{EXPERIMENTAL}

Se han preparado 17 soluciones sintéticas con una matriz común de $\mathrm{Ca}(\mathrm{OH})_{2}$ saturado $\left(8{\left.\mathrm{~g} . \mathrm{I}^{-1}\right)}^{-1}\right.$ en agua destilada. Sobre esta matriz se han añadido iones $\mathrm{Cl}^{-}$y $\mathrm{OH}^{-}$en diferente concentraciones, obteniendo relaciones $\left[\mathrm{Cl}^{-}\right] /\left[\mathrm{OH}^{-}\right]$en un rango comprendido entre 0 y 71. Todos los reactivos empleados han sido Merck AR.

Al principio y al final de cada experiencia se han realizado análisis cuantitativos de los iones. $\mathrm{El} \mathrm{Ca}^{2+}$ se ha valorado
Both in carbonation as when the chlorides enter from an external medium, the work life of a corroding structure can be distinguished into two periods: a) an initiation period which expresses the time the aggressive agent takes to reach the reinforcement, when the steel despassivate and $b$ ) a propagation period when the steel is being actively corroded.

In the case of chlorides, at present, many studies have been carried out (2-4) concerning with the bondbreaking potential (Er) or the amount of chloride required to despassivate the reinforcements in a so alkaline medium (limit of $\left[\mathrm{Cl}^{-}\right] /\left[\mathrm{OH}^{-}\right]$). However, there are many works intended to establish a relationship between the amount of chlorides and the corrosion rate in the reinforcements, i.e., its influence on the propagation period of the corrosion.

The corrosion velocity of a steel in concrete depends majorly on its humidity content (which, in turn, limits the $\mathrm{O}_{2}$ availability and resistance) and its temperature. When corrosion is due to chlorides, there are experimental evidences (5-7) that these ions also affect the corrosion rate. However, quantitative relationship has not yet been established between them.

The authors of this paper, by exploring systematically the parametres affecting the corrosion velocity of steel in concrete, give here, the results derived from the corrosion of steel in solutions which simulate the aqueous phase of a concrete containing chlorides. For this goal, several solutions with $\mathrm{pH}$ range 11,64 and 13,22 has been prepared with different additions of $\mathrm{NaCl}$ and $\mathrm{CaCl}_{2}$ These solutions have been characterized by their ionic strength, resistance and $[\mathrm{Cl}] /\left[\mathrm{OH}^{-}\right]$ ratio and then, these parametres have been compared to the corrosion rate obtained from measurements of Polarization Resistance.

\section{EXPERIMENTAL}

Seventeen synthetic solutions have been prepared with a common matrix of saturated $\mathrm{Ca}(\mathrm{OH})_{2}$ in destilled water. On this matrix, it has been added $\mathrm{Cl}^{-}$and $\mathrm{OH}^{-}$ions at different concentrations, obtaining $[\mathrm{Cl}] /\left[\mathrm{OH}^{-}\right]$ratio range around 0 and 71 . All the reactives employed have been Merck AR.

At the beginning and at the end of each experiment, it has been carried out a quantitative analysis of the ions. $\mathrm{Ca}^{2+}$ has been 
complexométricamente con soluciones de EDTA 0,01 $\mathrm{M}$ empleando calceína como indicador. $\mathrm{El}$ ión $\mathrm{OH}^{-}$, frente a $\mathrm{HCl} 0,01 \mathrm{M} \mathrm{y}$ fenoftaleina, el $\mathrm{Na}^{+}$y $\mathrm{K}^{+}$por fotometria de llama y el Cl por valoración con $\mathrm{AgNO}_{3}$. Las medidas de $\mathrm{pH}$ se realizaron con un electrodo combinado de vidrio empleando un $\mathrm{pH}$ metro Orion 901. Las medidas de conductividad se hicieron en un Conductímetro Crison 525 mediante una célula conductimétrica de electrodos de platino.

En la Tabla I recogen los datos más significativos de todas las soluciones. Como se puede ver, existe una diferencia notable de los valores de $\mathrm{pH}$ en función del $\mathrm{NaCl}$ o $\mathrm{CaCl}_{2}$ añadido, siendo más bajos en el caso del $\mathrm{CaCl}_{2}$ debido a la reacción de precipitación del $\mathrm{Ca}(\mathrm{OH})_{2}$ que, a su vez, es función de su concentración (ver n. 15 en Tabla I). evaluated complexometrically with EDTA $0,01 \mathrm{M}$ solutions employing calceine as indicator. $\mathrm{OH}^{-}$ion, by $\mathrm{HCl} 0,01 \mathrm{M}$ and fenoftaleine $\mathrm{Na}^{+}$and $\mathrm{K}^{+}$by flame fotometry and $\mathrm{Cl}$ by titration with $\mathrm{AgNO}_{3}$. The measurements of $\mathrm{pH}$ were carried out with a glass combined electrode employing a $\mathrm{pH}$ metre Orion 901.

The measurements of conductivity were carried out by a conductiometre Crison 525 and conductimetric cell of platinum electrodes.

Table I shows the most significant data of the solutions tested. As it can be observed, there is remarkable difference of $\mathrm{pH}$ values as a function of $\mathrm{NaCl}$ or $\mathrm{CaCl}_{2}$ added, where $\mathrm{CaCl}_{2}$ has lower $\mathrm{pH}$ values due to the precipitation reaction of $\mathrm{Ca}(\mathrm{OH})_{2}$, which, in turn, is a function of its concentration (See no. 15 in Table I).

TABLA I (TABLE I)

Caracterización de las soluciones sintéticas (Characterization of synthetic pore solution)

\begin{tabular}{|c|c|c|c|c|c|c|c|c|c|c|}
\hline $\mathbf{N} .^{\circ}$ & $\begin{array}{l}\text { KOH } \\
(\mathrm{N})\end{array}$ & $\begin{array}{l}\mathrm{NaCl} \\
(\mathrm{N})\end{array}$ & $\underset{(\mathrm{N})}{\mathrm{CaCl}_{2}}$ & $\mathrm{pH}_{\mathrm{m}}$ & $\underset{(\mathrm{M})}{\left[\mathrm{OH}^{-}\right]_{v}}$ & $\begin{array}{c}{\left[\mathrm{Ca}^{2-1}\right]} \\
(\mathrm{M})\end{array}$ & {$\left[\mathrm{Cl}^{-}\right] /\left[\mathrm{OH}^{-}\right]$} & $\begin{array}{c}\text { Icorr. } \\
\left(\mu A \cdot \mathrm{cm}^{-2}\right)\end{array}$ & $\begin{array}{c}\rho \\
(\Omega \cdot \mathrm{cm})\end{array}$ & $\stackrel{\mu}{f(M)}$ \\
\hline 1 & - & 0.5 & - & 12.36 & 0.06 & 0.03 & 8.3 & 1.6 & 18 & 0.6 \\
\hline 2 & - & 0.75 & - & 12.36 & 0.06 & 0.03 & 12.3 & 1.6 & 13 & 0.8 \\
\hline 3 & 0.2 & - & - & 13.02 & 0.20 & 0.004 & 0 & 0.06 & 25 & 0.2 \\
\hline 4 & 0.2 & 0.1 & - & 13.02 & 0.20 & 0.004 & 0.5 & 0.2 & 20 & 0.3 \\
\hline 5 & 0.2 & 0.5 & - & 12.85 & 0.17 & 0.005 & 3.0 & 0.9 & 13 & 0.7 \\
\hline 6 & 0.2 & 0.75 & - & 12.82 & 0.17 & 0.005 & 4.4 & 1.0 & 10 & 0.9 \\
\hline 7 & 0.2 & 1.0 & - & 12.80 & 0.20 & 0.004 & 5.0 & 1.15 & 9 & 1.2 \\
\hline 8 & 0.5 & 0.5 & - & 13.22 & 0.42 & 0.001 & 1.2 & 0.46 & 8 & 1.0 \\
\hline 9 & 0.5 & 0.75 & - & 13.17 & 0.40 & 0.001 & 1.9 & 0.54 & 7 & 1.2 \\
\hline 10 & - & - & 0.5 & 11.96 & 0.04 & 0.23 & 13.5 & 1.8 & 21 & 0.7 \\
\hline 11 & - & - & 0.75 & 11.90 & 0.04 & 0.37 & 19.0 & 2.1 & 16 & 1.1 \\
\hline 12 & 0.2 & - & 0.1 & 12.66 & 0.10 & 0.005 & 1.0 & 0.4 & 30 & 0.2 \\
\hline 13 & 0.2 & - & 0.5 & 12.04 & 0.04 & 0.18 & 12.5 & 1.6 & 21 & 0.7 \\
\hline 14 & 0.2 & - & 0.75 & 11.90 & 0.04 & 0.30 & 19.0 & 2.0 & 16 & 1.1 \\
\hline 15 & 0.2 & - & 1.0 & 11.64 & 0.01 & 0.30 & 71.0 & 6.6 & 13 & 1.2 \\
\hline 16 & 0.5 & - & 0.5 & 12.24 & 0.04 & 0.07 & 12.5 & 1.6 & 18 & 0.7 \\
\hline 17 & 0.75 & - & 0.75 & 12.02 & 0.04 & 0.20 & 19.0 & 2.2 & 14 & 1.0 \\
\hline
\end{tabular}

La célula de corrosión empleada es similar a la descrita en un trabajo previo (8). Como electrodos de trabajo se utilizan tres barras idénticas (en cada célula) de acero de $5,4 \mathrm{~mm}$ de diámetro, pulidas, desengrasadas y pesadas; una cuarta barra de carbón se emplea como electrodo auxiliar. El área de exposición al ataque electroquímico, de $4,2 \mathrm{~cm}^{2}$, se delimita con cinta aislante. Las soluciones se mantienen en baños
The corrosion cell employed is similar to the one described in a previous paper (8). As working electrodes, three identical steel rods of $5.1 \mathrm{~mm}$ diametre, were employed (in each cell). and a forth rod of carbon employed as a suplementary electrode. The area exposed to electrochemical attack is $4.2 \mathrm{~cm}^{2}$. which is limited with isolating tape. The solutions are kept in thermostated baths at $21^{\circ} \mathrm{C}$ along the time the experiment lasts. 
termostatados a $21^{\circ} \mathrm{C}$ durante todo el tiempo que dura la experiencia.

\section{Técnica de medida}

La Resistencia de Polarización ha sido la técnica empleada para medir la evolución de la velocidad de corrosión con el tiempo, según la forma descrita en anterior trabajo (8). La intensidad de corrosión se calcula a partir de la ecuación de Stern-Geary (9) empleando un valor de la cte. B de $26 \mathrm{mV}$ o $52 \mathrm{mV}$, cuando el acero se corroe activamente o cuando el acero se conserva pasivo. Las pérdidas de peso electroquímicas se contrastan con las obtenidas por pesada de los aceros antes y después de la experimentación (Fig. 1). Los potenciales de corrosión se han medido frente a un electrodo de referencia de calomelanos saturados empleando un Potenciostato Amel 551 con compensación electrónica de la caída óhmica.

\section{Techniques}

The Polarization Resistance has been the technique employed to evaluate the corrosion rate along time, according to the description given in a previous paper (8). The corrosion intensity is calculated from Stern-Geary's equation (9) employing a constant $B=26 \mathrm{mV}$ or 52 when the steel is actively corroding or when the steel remains passive. The electrochemical weight losses are compared to those obtained by weighing the steel prior and after the experiments (Fig. 1).

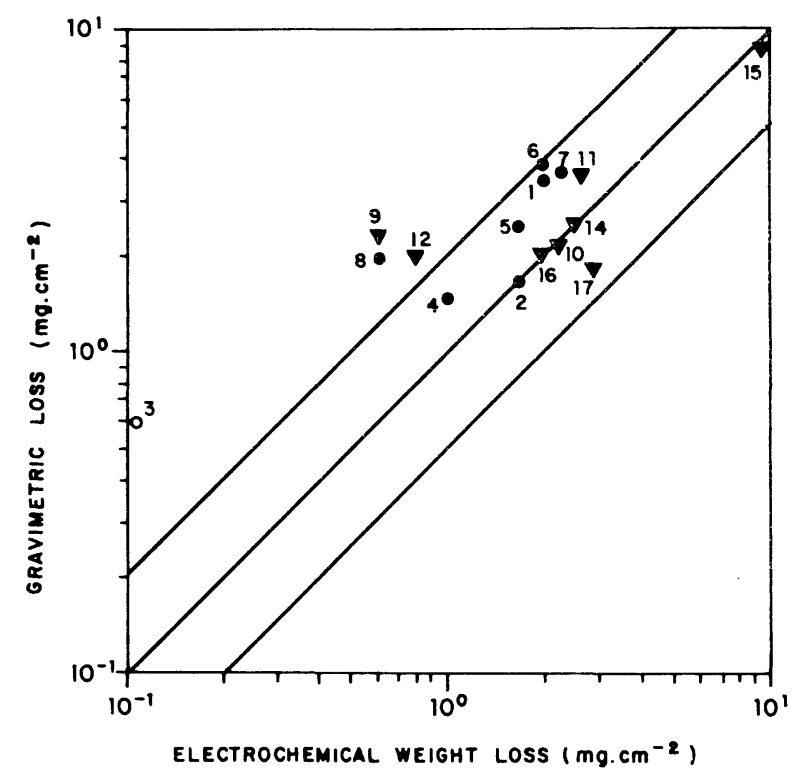

Fig. 1.-Comparación de las pérdidas de peso calculadas electroquímicamente y gravimétricamente.

Fig. 1.-Comparison between electrochemical and gravimetric weight loss.

Los datos de intensidad de corrosión que aparecen en la Tabla I son unos valores medios obtenidos a partir de su integral en el tiempo, dividida por el número de días de duración de cada experimento. Esto se ha hecho asi a fines comparativos puesto que, por los general, la Icorr. instantánea aumentaba bruscamente a partir de un cierto tiempo, sin conseguir obtener un equilibrio.
The corrosion potentials have been measured employing a saturated calomel reference electrode using a Potentiostate Amel 551 with ohmic drop compensation. The data of corrosion intensities shown in Table I, are the average values obtained from their integral along time divided by the number of days of each test. This has been made so in order to establish a comparison, since, in general, the instantaneous lcorr raises drasctically from a certain period of time, without reaching an equilibrium. 


\section{RESULTADOS Y DISCUSION}

\section{Variación de la Resistividad en función del pH}

Como puede verse en la figura 2, existe una relación lineal entre la resistividad y el $\mathrm{pH}$ para cada una de las concentraciones de ión $\mathrm{Cl}$ estudiadas, obteniendo un abanico de rectas que tienden a confluir a valores altos de $\mathrm{pH}-13,70$. La contribución del ión $\mathrm{Cl}^{-}$a la resistividad total de la solución es más acuosa a bajos pHs. La explicación que se ha dado a este hecho, se basa en que el ión $\mathrm{OH}^{-}$tiene un valor de conductividad equivalente a dilución infinita de 198 en comparación con 78,4 del ión $\mathrm{Cl}^{-}$. Por lo tanto a altos $\mathrm{pHs}$ prevalecerá la conductividad del ión $\mathrm{OH}^{-}$sobre el $\mathrm{Cl}^{-}$en el valor global de la conductividad específica (o su inversa la resistividad). Sin embargo, a bajos pHs la contribución del ión $\mathrm{Cl}^{-}$en función de su concentración es bien diferenciada.

\section{RESULTS AND DISCUSSION}

\section{Variation of the Resistivity as a function of pH}

As it can be observed in Fig. 2, there is a linear relationship between the resistivity and the $\mathrm{pH}$ for each one of the concentration of $\mathrm{Cl}^{-}$ions tested, obtaining a range of rects that tend to be equal at high $\mathrm{pH}$ value $=13,70$. The contribution of the $\mathrm{Cl}$ ion to the solution resistivity is more remarkable at low $\mathrm{pHs}$. The explanation given to this point is based on the fact that the $\mathrm{OH}^{-}$ion has a value of equivalent at infinite dilution of 198 in comparison to $\mathrm{Cl}^{-}$ ion with 78,4 . Thus, at high $\mathrm{pHs}$, the conductivity of $\mathrm{OH}^{-}$will prevail over $\mathrm{Cl}^{-}$in the overall value of the specific conductivity (or its inverse, the resistivity).

However, at low $\mathrm{pHs}$ the contribution of $\mathrm{Cl}^{-}$ion as a function of its concentration is quite differentiated.

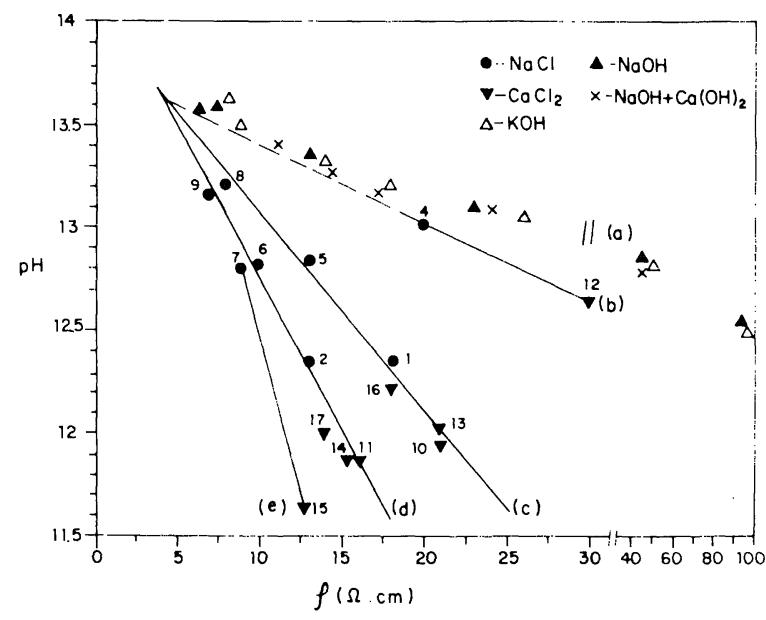

Fig. 2.-Variación de la Resistividad en función del $\mathrm{pH}$. (a) $0 \mathrm{~N}$ en $\mathrm{Cl}^{-}$, (b) $0,1 \mathrm{~N}$, (c) 0,5, (d) 0,75 $\mathrm{N}$ y (e) $1 \mathrm{~N}$.

Fig. 2. -Variation of Resistivity in function of the $\mathrm{pH}$ value (a) $0 \mathrm{~N}$ en $\mathrm{Cr}^{-}$. (b) $0,1 \mathrm{~N}$. (c) 0.5 , (d) $0,75 \mathrm{~N}$ and (e) $1 \mathrm{~N}$.

\section{Comportamiento Electroquímico}

En las figuras 3, 4 y 5 se representan los valores instantáneos de la Icorr. y la Ecorr. en función del tiempo, siendo cada punto la media de tres resultados. La zona rayada en las gráficas indica una frontera aproximada entre la lcorr. considerada significante y la Icorr. despreciable.

La influencia de la concentración del ión $\mathrm{Cl}^{-}$ $(\mathrm{NaCl})$ para una cantidad cte. de $\mathrm{KOH}$ se

\section{Electrochemical behaviour}

In fig. 3, 4 and 5, it has been represented the instataneous values of the Icorr. and Ecorr. as functions of time, in which each point is the average of three results. The shaded area in the charst show the approximate boundary bewteen significant lcorr. and unsignificant ones.

The influence of the $\mathrm{Cl}^{-}(\mathrm{NaCl})$ ion concentration for a constant amount of $\mathrm{KOH}$, is 
recoge en la Fig. 3. Como puede verse, en ausencia de $\mathrm{NaCl}$ [curva (a) en Fig. 3] la Icorr. se mantiene prácticamente por debajo del valor $0,2 \mu \mathrm{A}$ y los Ecorr. correspondientes alcanzan valores de $100 \mathrm{mV}$. A medida que aumenta la concentración de $\mathrm{NaCl}$, los valores de Icorr. también lo hacen, con una clara diferencia entre los correspondientes a la concentración de $\mathrm{NaCl}$ de $0,1 \mathrm{~N}$ y 0,5-1 N. Por el contrario, los Ecorr. evolucionan hacia valores más negativos. Hay que destacar que la curva correspondiente a una concentración $1 \mathrm{~N}$, en $\mathrm{NaCl}$, no alcanza los valores de Icorr. que se experarian debido a su alta concentración en ión $\mathrm{Cl}^{-}$. La explicación a este fenómeno, como veremos más adelante, puede encontrarse en la elevada fuerza iónica del medio que resta movilidad iónica y por lo tanto actividad del ión $\mathrm{Cl}^{-}$.

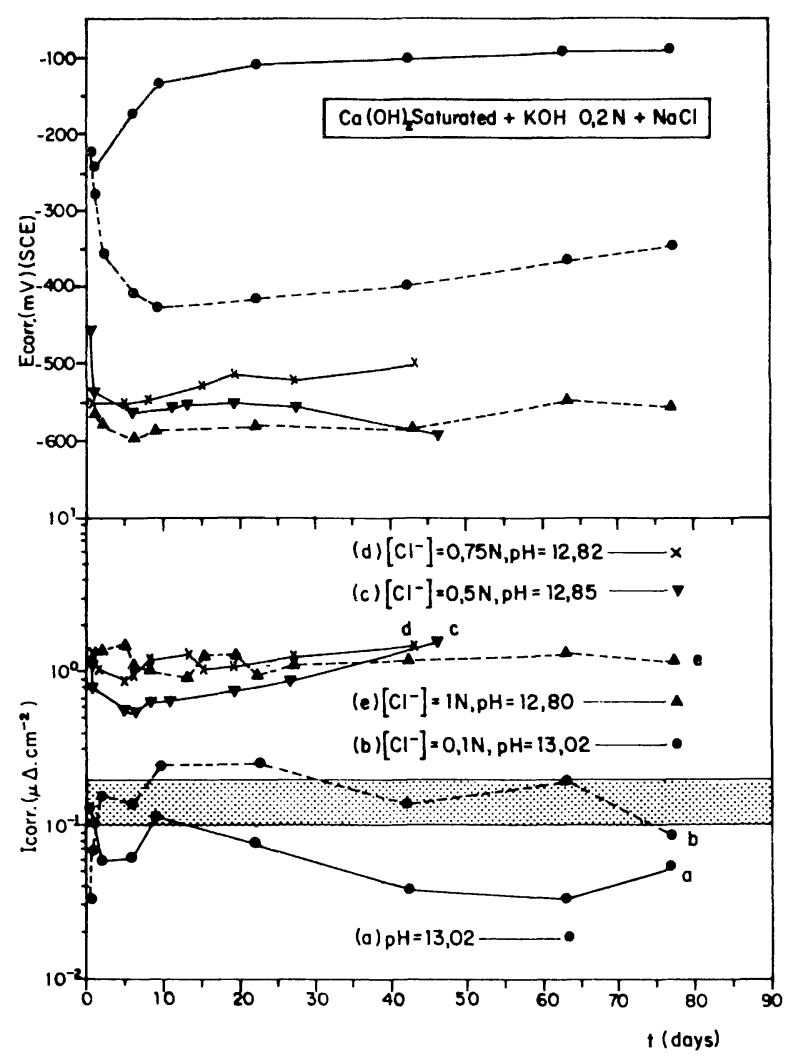

Fig. 3.- Variación de la Intensidad y Potencial de Corrosión con el tiempo. Influencia de la concentración del ion $\mathrm{Cl}^{-}(\mathrm{NaCl})$.

Fig. 3.-Variation of Corrosion Potential and instantaneous Intensity in time. Influence of chloride concentration $(\mathrm{NaCl})$.

En el caso del $\mathrm{CaCl}_{2}$ (Fig. 4), los pHs bajan considerablemente en función de la concentración añadida, debido a la reacción de precipitación del $\mathrm{Ca}(\mathrm{OH})_{2}$ antes shown in Fig. 3. As it can be observed, in absence of $\mathrm{NaCl}$ (curve (a) in Fig. 3) the Icorr. remains essentially below the value $0,2 \mu \mathrm{A} \mathrm{cm}^{2}$ and the respective Ecorr. reach values of $-100 \mathrm{mV}$. As the concentration of $\mathrm{NaCl}$ increases, the Icorr. raises too, with a clear difference between those corresponding to a $\mathrm{NaCl} 0,1 \mathrm{~N}$ and 0,5-1 $\mathrm{N}$ concentration. On the contrary, the Ecorr. evolves towards more negarive values. It must been pointed out that the curve correponding to a $\mathrm{NaCl} 1 \mathrm{~N}$ concentration does not reach the lcorr. that would be expectable due to the high concentration of $\mathrm{Cl}$. The explanation of this phenomenom, as we shall see below, may be found in the fact that the high ionic strength of the medium decreases ionic movility and therefore, activity to the $\mathrm{Cl}^{-}$ion.

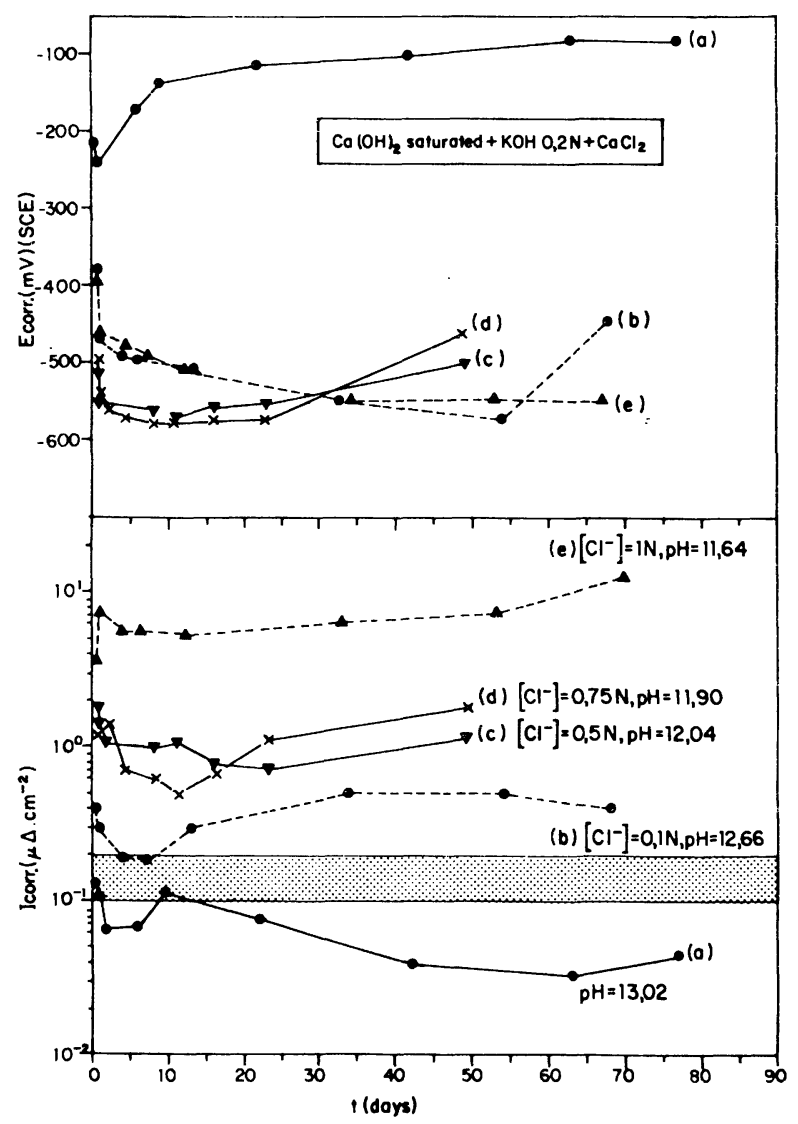

Fig. 4.- Variación de la Intensidad y Potenciales de Corrosión con el tiempo. Influencia de la concentración del ión $\mathrm{Cl}^{-}\left(\mathrm{CaCl}_{2}\right)$

Fig. 4.- Variation of the Corrosion Potential and instantaneous Intensity with time. Influence of chloride concentration $\left(\mathrm{CaCl}_{2}\right)$.

In the case $\mathrm{CaCl}_{2}$ (Fig. 4), the pHs fall remarkably as a function of the added concentration, due to the precipitation reaction of $\mathrm{Ca}(\mathrm{OH})_{2}$ formely mentioned, reaching, 
mencionada, alcanzándose por lo tanto para la misma concentración equivalente de ión $\mathrm{Cl}^{-}$ valores de Icorr. más elevados que los obtenidos con $\mathrm{NaCl}$. Asimismo los valores de Ecorr. se desplazan hacia zonas más negativas.

En cuanto a la influencia del pH (Fig. 5), y como era de esperar, para una concentración fija de $\mathrm{Cl}^{-}$la lcorr. menor se obtiene para el valor mayor de $\mathrm{pH}=13,22$, aunque en el caso de la concentración $0,75 \mathrm{~N}$ de $\mathrm{NaCl}$ las curvas correspondientes a los pHs 12,36 y 12,82 se entrecruzan prácticamente, desde el principio, sin establecer una diferencia clara entre ellas. Cuando la concentración de $\mathrm{NaCl}$ es $0,5 \mathrm{~N}$ a dichos pHs, las curvas también se entrecruzan, pero a partir de 20 días, sin obtener valores estables aún a los 50 dias.

En general, los valores de Icorr. disminuyen bruscamente al cabo del primer día, para empezar a subir después de 5 o 6 días sin llegar a alcanzar, casi en ningún caso, un equilibrio estable con el tiempo. Debido a esto, y para valorar cuantitativamente estos efectos, se ha considerado un valor medio de Icorr. en cada caso (ver Tabla I). therefore for the same equivalent concentration of $\mathrm{Cl}$ ions, higher Icorr. than those obtained with $\mathrm{NaCl}$. Similarly, the Ecorr. are shifted to more negative zones.

Regarding the influence of $\mathrm{pH}$ (Fig. 5), as it was expected, for a fixed concentration of $\mathrm{Cl}^{-}$, the lowest Icorr. is obtained for the highest $\mathrm{pH}$ value $=13,22$. However, in the case of $\mathrm{NaCl} 0,75 \mathrm{~N}$ concentration, the curves corresponding to $\mathrm{pHs} 12,36$ and 12,82 , are crossed almost from the very beginning, without a clear distiction between them. When $\mathrm{NaCl}$ concentration is 0,5 at those $\mathrm{pHs}$, the curves also cross each other though after 20 days, without reaching stable value even after 50 days.

In general, the lcorr. values fall drastically after the first day and then increase after 5 or 6 days without reaching. almost in any case, a stable equilibrium along time. For this reason and in order to evaluate quantitavely these effects, it has been taken a average Icorr. value for each case (See Table I)
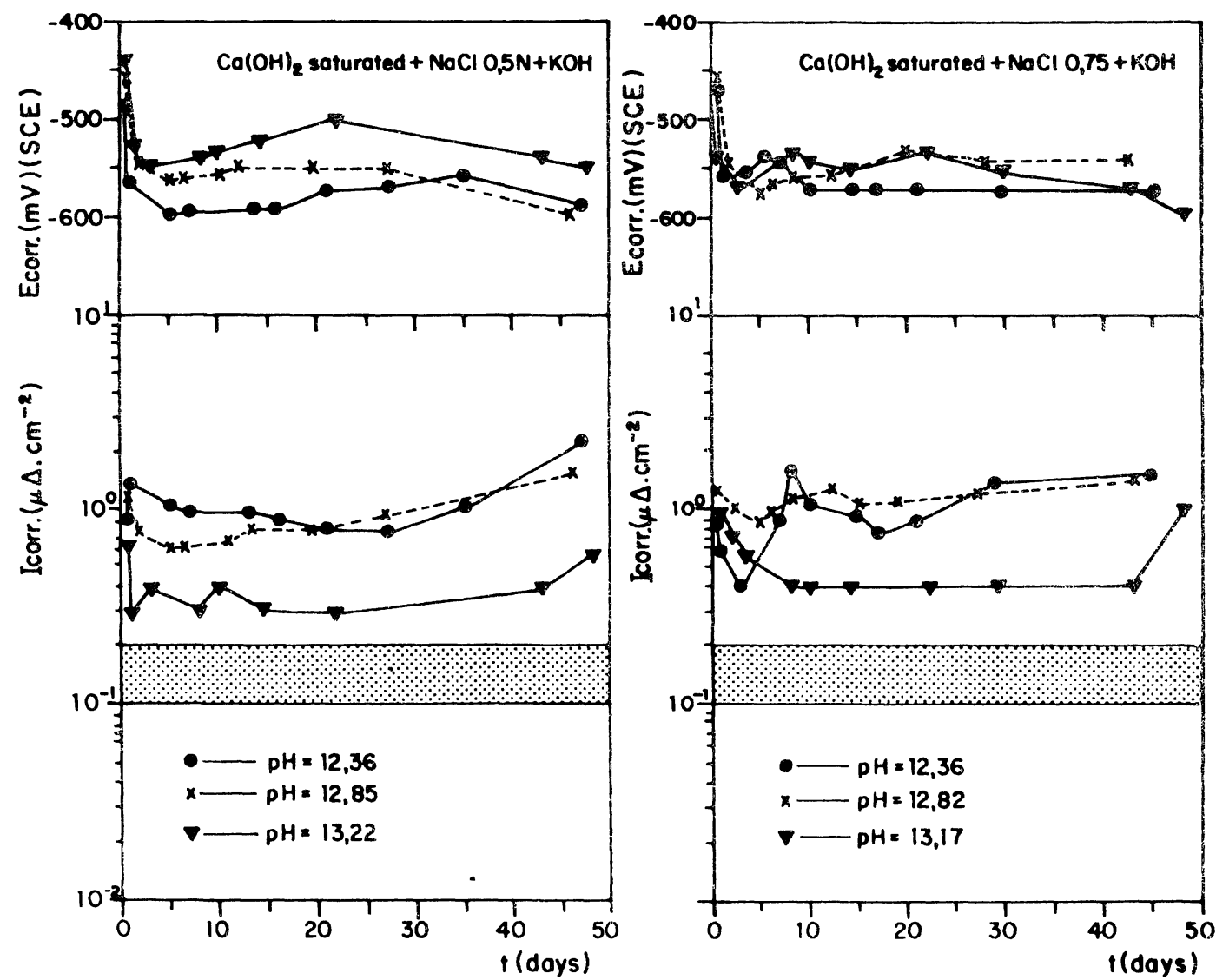

Fig. 5.- Variación de la Intensidad y Potenciales de Corrosión con el tiempo. Influencia del pH.

Fig. 5.-Variation of Corrosion Potential and instantaneous Intensity with time. Influence of the pH. 


\section{Variación de la Icorr. media en función de la Fuerza Iónica}

Como se observa en la figura 6 , cuando las variaciones de la fuerza iónica se deben a cambios en la concentración del $\mathrm{NaCl}$ (puntos n. ${ }^{\circ}$ 3, 4, 5, 6 y 7 en Fig. 6), la Icorr. media aumenta considerablemente a valores bajos de fuerza iónica, tendiendo a estabilizarse para altos valores de ésta. Lo mismo ocurre cuando las variaciones de fuerza iónica se deben a variaciones de $\mathrm{pH}$ (igual concentración de $\mathrm{Cl}^{-}$) [curvas (c) y (d) en Fig. 6]; a bajos valores de fuerza iónica, pequeñas variaciones de ésta producen grandes cambios de Icorr., sin embargo, estos cambios se hacen menores a altos valores de fuerza iónica. En el caso del $\mathrm{CaCl}_{2}$, el fenómeno es parecido, con la excepción del punto n. ${ }^{\circ} 15$, que no se ajusta al comportamiento de los demás quizá debido al bajo $\mathrm{pH}$ de la solución. Del análisis de esta figura se deduce que tanto el carácter agresivo de los iones $\mathrm{Cl}$ como el protector de los $\mathrm{OH}^{-}$disminuye a medida que aumenta la fuerza iónica, debido a la menor movilidad de los iones que hace disminuir su potencial actividad agresiva o protectora frente a la corrosión.
Variation of the average Icorr. as a function of the Ionic Strength

As it can be observed in Fig. 6, when the variations of the ionic strength are due to changes in the $\mathrm{NaCl}$ concentration (points no. 3, 4, 5, 6 and 7 Fig. 6), the average lcorr. increases remarkably to low ionic strength values, tending to reach an equilibrium at higher values of the latter ones. This also happens when the variations of the ionic strength are due to $\mathrm{pH}$ variations (equal concentration of $\mathrm{Cl}^{-}$) (curves (c) and (d) in Fig. 6), at low ionic strength values, small variations produce sharp changes in the lcorr. However, these changes are lower at high ionic strength values. In the case of $\mathrm{CaCl}_{2}$, the phenomenom is similar, excepting that the point no. 15 does not suit to the general behaviour due probably to the solution low $\mathrm{pH}$. Analysing this figure, we can imply that both the aggresive character of $\mathrm{Cl}$ ions as the protector character of $\mathrm{OH}^{-}$decrease as the ionic strength increases, due to the lower movility of the ions that make fall their aggressive or protector activity in the corrosion.

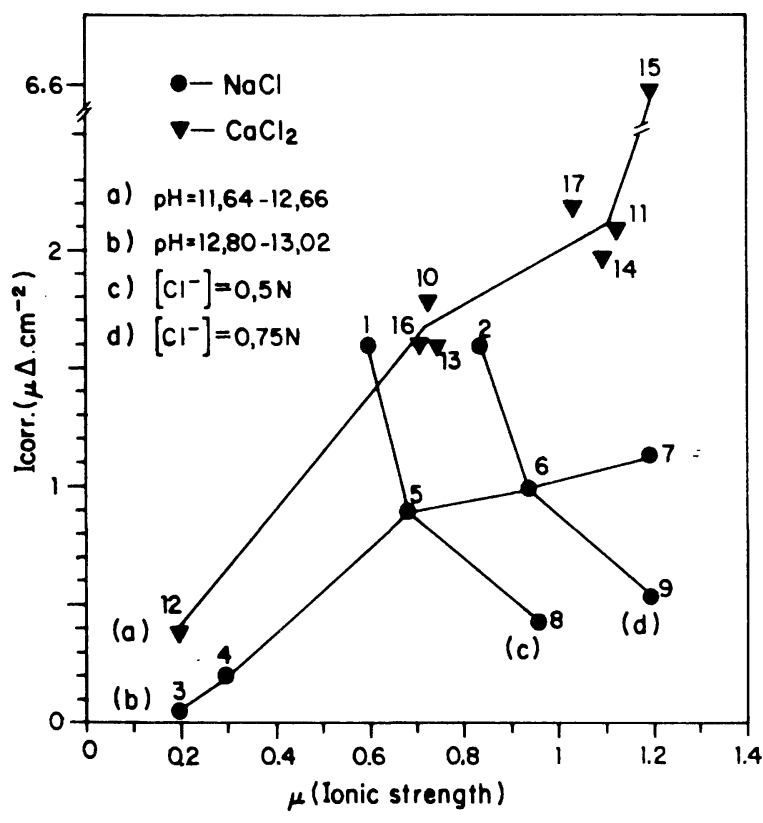

Fig. 6.- Variación de la Intensidad de Corrosión en función de la Fuerza iónica.

Fig. 6.-Variation of the Mean Corrosion Intensity in function of the toma strength.

\section{Variación de la lcorr. media en función de la Resistividad}

Si enfrentamos los valores de Icorr. media con los de resistividad (Fig. 7), obtenemos unas
Variation of the average Icorr. as a function of the Resistivity

If we match the average Icorr values with those of the resistivity (fig. 7) it is obtained a linear 
relaciones lineales (escala doble logarítmica) entre ellos. Como puede verse, para un $\mathrm{pH}$ dado, la lcorr. disminuye al aumentar la resistividad (por una disminución de la concentración del ión $\mathrm{Cl}^{-}$) [ver rectas (a) y (b) en Fig. 7l. Sin embargo, para una concentración fija de $\mathrm{Cl}$, la lcorr. aumenta con la resistividad (disminución del $\mathrm{pH}$ ) [ver rectas (c) y (d) en Fig. 7]. El desplazamiento entre las rectas (a) y (b) es debido al diferente $\mathrm{pH}$ y contenido en $\mathrm{Ca}^{2+}$ de las disoluciones de $\mathrm{CaCl}_{2}$.

De la observación de esta figura se puede deducir el papel antagónico que los iones $\mathrm{Cl}^{-}$y $\mathrm{OH}^{-}$juegan en el proceso de la corrosión.

Por último, si representamos la relación $\left[\mathrm{Cl}^{-}\right] /\left[\mathrm{OH}^{-}\right]$de concentraciones frente a la lcorr. media (en escala doble logarítmica) (Fig. 8) se obtiene una línea recta de pendiente 0,6, donde se ajustan todos los puntos.

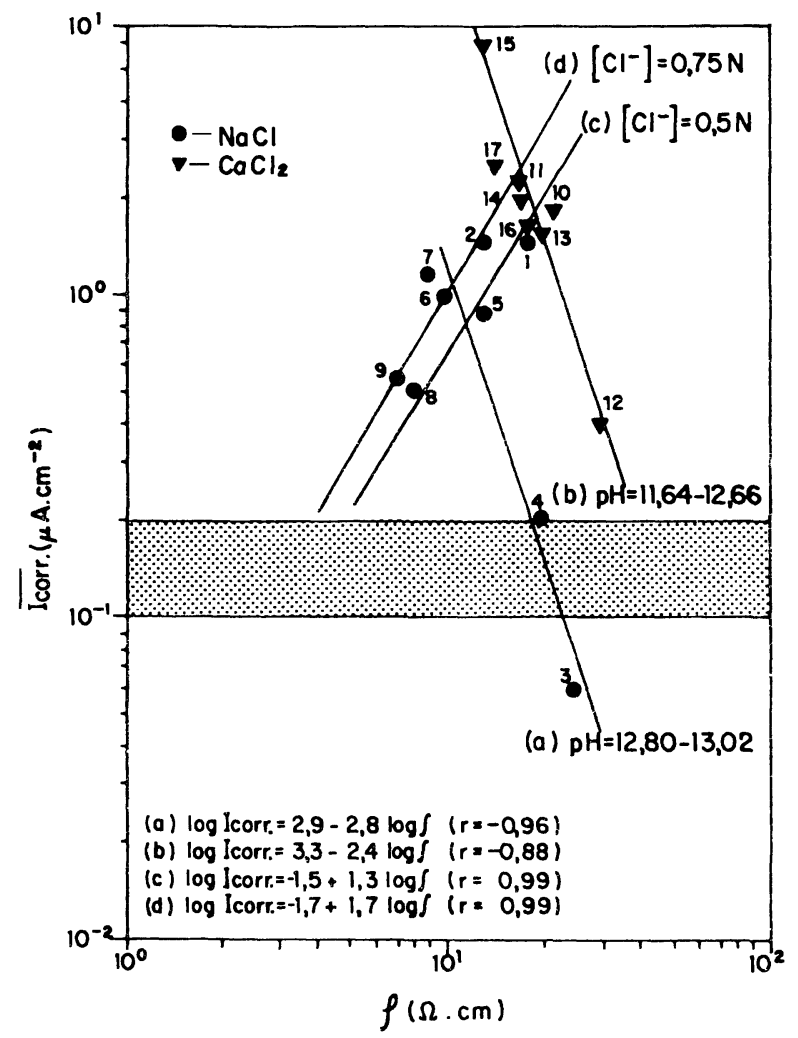

Fig. 7.-Variación de la Intensidad media de Corrosión en función de la Resistividad.

Fig. 7.-Variation of the Mean Corrosion Intensity in function of the Resistivity.

\section{CONCLUSIONES}

De los resultados obtenidos pueden deducirse las siguientes conclusiones: relationship (double logarithm scale) between them. As it can be observed, for a given $\mathrm{pH}$, the lcorr. falls as the resistivity increases (due to a decrease in the $\mathrm{Cl}$ ion concentration) [See lines (a) and (b) in Fig. 7]. However, for a fixed $\mathrm{Cl}$ concentration, the lcorr. increases with the resistivity ( $\mathrm{pH}$ decrease) [See lines (c) and (d) in Fig. 7]. The shift between line (a) and (b) is due to their different $\mathrm{pHs}$ and content of $\mathrm{Ca}^{2+}$ in the $\mathrm{CaCl}_{2}$ solutions.

Analysing this figure we can imply the antagonic role played by $\mathrm{Cl}^{-}$and $\mathrm{OH}^{-}$ions in the corrosion process.

Finally, if we represent the [Cl $\mathrm{V}\left[\mathrm{OH}^{-}\right]$ concentration ratio against the average lcorr. (in double logaritm scale) (Fig. 8) it is obtained a straight line with slope $=0,6$ which suits all the points.

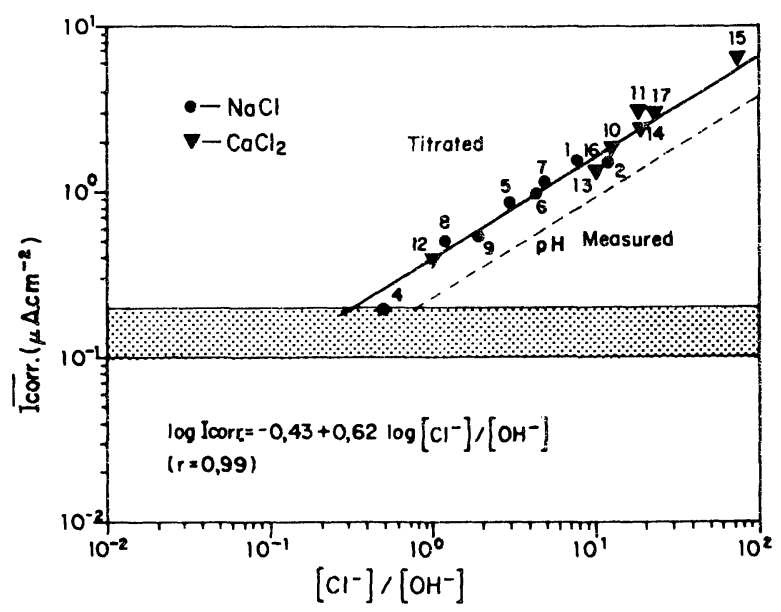

Fig. 8.-Variación de la Intensidad media de Corrosión en función de la relación de concentraciones [ $\mathrm{Cl}^{-} ! /\left[\mathrm{OH}^{\top}\right]$.

Fig. 8.-Variation of the Mean Corrosion Intensity in function of the $\left[\mathrm{Cl}^{-}\right] /\left[\mathrm{OH}^{-}\right]$ratio.

\section{CONCLUSIONS}

From the results obtained in this work, we can imply the following conclusions: 
1) $\mathrm{El}$ efecto antagónico de los iones $\mathrm{Cl}^{-}$y $\mathrm{OH}^{-}$ en el fenómeno de la corrosión se pone de manifiesto indirectamente a través de las variaciones de los parámetros de solución, fuerza iónica y resistividad a que estos iones dan lugar.

2) Altos valores de fuerza iónica disminuyen la movilidad de los iones y, por lo tanto, su potencial actividad agresiva o inhibidora a la corrosión.

3) El efecto de la conductividad del ión $\mathrm{Cl}^{-}$, en el valor global de la conductividad específica, va disminuyendo a medida que aumenta el $\mathrm{pH}$, anulándose para un valor límite de $\mathrm{pH}=13,70$ sea cual fuere su concentración.

4) Una relación lineal (en escala doble logarítmica) se obtiene entre la relación de concentraciones [ $\left.\mathrm{Cl}^{-}\right] /\left[\mathrm{OH}^{-}\right]$y la lcorr. media, a partir de la cual se puede calcular el límite de los primeros que originan valores de Icorr. $<0,2 \mu$ A.cm-2 .
1) The anatagonic effect of $\mathrm{Cl}^{-}$and $\mathrm{OH}^{-}$ions in the corrosion phenomenom is indirectly shown out by the parameter variations of the solutions, ionic strength and resistivity that these ions give result.

2) High ionic strength values decrease ion movility and therefore, decrease their aggressive or protector potential character in the corrosion process.

3) The conductivity effect of $\mathrm{Cl}^{-}$ion in the overall of the specific conductivity decreases as increases the $\mathrm{pH}$, and it is anulled for a $\mathrm{pH}$ limit value $=13,70$ whatever the concentration may be.

4) A linear relatioship (in double logarithm scale) is obtained between the $[\mathrm{Cl}] /\left[\mathrm{OH}^{-}\right]$ ratio and the average lcorr. from which it can be evaluated the limit of the formers which gives as results lcorr. values $<0,2 \mu A$. $\mathrm{cm}^{2}$.

\section{BIBLIOGRAFIA}

(1) TUUTTI K.: Corrosion of Steel in Concrete, Swedish Cement and Concrete Research Institute Stockholm. Research Report n. ${ }^{\circ}$; 289 (1982).

(2) HAUSMANN D. A.: Steel Corrosion in Concrete, Mater. Prot., Vol. 6: 19 (1967).

(3) GOUDA V. K.: Corrosion and Corrosion Inhibition of Reinforcing Steel, I. Immersed in Alkaline Solution, Br. Corros. J., Vol. 5: 198 (1970).

(4) HARROP D.: A Galvanostatic and Potentiodynamic Study of the Corrosion Behaviour of Mild Steel in Saturated Calcium Hydroxide Solution and Embedded Mortar in the Presence of Chloride Ion, British Research Establishment Pub. n. ${ }^{\circ} 116$ (1977).

(5) ANDRADE C. and PAGE C. L.: Pore Solution Chemistry and Corrosion in Hydrated Cement Systems Containing Chloride Salts: A Study of Cation Specific Effects, Br. Corros. J., Vol. 21 (1): 49 (1986).

(6) ANDRADE C., ALONSO C., GOÑI S. y GONZALEZ J. A.: Corrosion de Armaduras en Hormigones en Contacto con Agua de Mar: el Efecto de la Galvanización y el Uso de Nitrito con Inhividor, 7th Int. Congress on Marine Corrosion and Fouling. Valencia (Spain) Nov. (1988).

(7) YONEZAWA T., ASHWORTH V. and PROCTER R. P.: Pore Solution Composition and Chloride Effects on the Corrosion of Steel in Concrete, Corrosion engineering Vol. 44 (7): 489 (1988).

(8) ANDRADE C. and CONZALEZ J. A.: Quantitative Measurements of Corrosion Rate if Reinforcing Steels Embedded in Concrete Using Polarization Resistance Measurements, Werkst. Korros. Vol. 29: 515, (1978).

(9) STERN M. and GEARY A. L.: A theorical Analysis of the Shape of Polarization Curves J. of the Elect. Soc. Vol. 104 (1): 56 (1957). 